OPEN ACCESS

Edited by:

Fabricio Eulalio Leite Carvalho,

Corporacion Colombiana

de Investigacion Agropecuaria (Agrosavia) - Cl La Suiza, Colombia

Reviewed by:

Shabir Hussain Wani

Sher-e-Kashmir University

of Agricultural Sciences

and Technology, India

Martina Spundova,

Palacký University, Olomouc, Czechia

Ana Karla M. Lobo,

São Paulo State University, Brazil

*Correspondence: Hermann Restrepo-Díaz hrestrepod@unal.edu.co

Specialty section:

This article was submitted to

Plant Physiology,

a section of the journal

Frontiers in Plant Science

Received: 30 April 2021

Accepted: 29 June 2021

Published: 21 July 2021

Citation:

Chávez-Arias CC,

Ligarreto-Moreno GA,

Ramírez-Godoy $A$ and

Restrepo-Díaz H (2021) Maize Responses Challenged by Drought.

Elevated Daytime Temperature and Arthropod Herbivory Stresses:

A Physiological, Biochemical

and Molecular View.

Front. Plant Sci. 12:702841.

doi: 10.3389/fp/s.2021.702841

\section{Maize Responses Challenged by Drought, Elevated Daytime Temperature and Arthropod Herbivory Stresses: A Physiological, Biochemical and Molecular View}

\author{
Cristhian Camilo Chávez-Arias, Gustavo Adolfo Ligarreto-Moreno, \\ Augusto Ramírez-Godoy and Hermann Restrepo-Díaz* \\ Universidad Nacional de Colombia, Sede Bogotá, Facultad de Ciencias Agrarias, Departamento de Agronomía, Bogotá, \\ Colombia
}

Maize (Zea mays L.) is one of the main cereals grown around the world. It is used for human and animal nutrition and also as biofuel. However, as a direct consequence of global climate change, increased abiotic and biotic stress events have been reported in different regions of the world, which have become a threat to world maize yields. Drought and heat are environmental stresses that influence the growth, development, and yield processes of maize crops. Plants have developed dynamic responses at the physiological, biochemical, and molecular levels that allow them to escape, avoid and/or tolerate unfavorable environmental conditions. Arthropod herbivory can generate resistance or tolerance responses in plants that are associated with inducible and constitutive defenses. Increases in the frequency and severity of abiotic stress events (drought and heat), as a consequence of climate change, can generate critical variations in plant-insect interactions. However, the behavior of herbivorous arthropods under drought scenarios is not well understood, and this kind of stress may have some positive and negative effects on arthropod populations. The simultaneous appearance of different environmental stresses and biotic factors results in very complex plant responses. In this review, recent information is provided on the physiological, biochemical, and molecular responses of plants to the combination of drought, heat stress, and the effect on some arthropod pests of interest in the maize crop.

Keywords: Zea mays L, stress combination, climate change, drought, high temperature, herbivorous arthropods

\section{INTRODUCTION}

Plants are exposed to a wide range of abiotic and biotic stresses that induce a disruption in plant metabolism (Atkinson and Urwin, 2012; Zhang and Sonnewald, 2017; Vemanna et al., 2019) which, in turn, leads to a reduction in growth and yield (Rejeb et al., 2014; Pandey et al., 2017). These types of stresses are common in many agricultural areas around the world, and represent one of the main 
threats of interest to crop productivity worldwide (Sewelam et al., 2014; Chojak-Koźniewska et al., 2018). Drought (water deficit in the soil or plant water scarcity), heat (elevated air temperature), cold, salinity, high light intensity, high $\mathrm{CO}_{2}$ concentrations, weeds, diseases, and pests are some of the abiotic and biotic stresses that have been studied the most (Suzuki et al., 2014; Pandey et al., 2017). The majority of the studies on the different types of stresses have been carried out individually and under controlled conditions, whereas field studies generally show the effect of the combination of such factors (Mittler, 2006; Suzuki, 2016a). The combination of two or more types of stress is common in many agricultural areas of the world, causing considerable reductions in crop yields (Table 1; Suzuki et al., 2014; Ahmad et al., 2019).

In recent decades, global warming due to climate change has been accelerated by the higher concentration of $\mathrm{CO}_{2}$ in the atmosphere. This phenomenon is generating an increase in the average temperature, alterations of precipitation patterns, and reduction of arable land and water resources in agricultural areas of the world (Ahmad et al., 2019; Dong et al., 2020). Additionally, complex combinations of abiotic stresses such as drought and

TABLE 1 | Impact of the different combinations of environmental stresses on the plant.

\begin{tabular}{|c|c|c|}
\hline Combination & Stress combinations & References \\
\hline \multirow[t]{19}{*}{ Negative combination } & Drought + heat & $\begin{array}{l}\text { Zandalinas et al., 2018; } \\
\text { Cohen et al., } 2021\end{array}$ \\
\hline & Drought + salinity & Sahin et al., 2018 \\
\hline & Drought + chilling & Hussain et al., 2018 \\
\hline & Drought + UV & $\begin{array}{l}\text { Rodríguez-Calzada et al., } \\
2019\end{array}$ \\
\hline & Drought + pathogen & Tani et al., 2018 \\
\hline & Drought + pets & Shehzad et al., 2021 \\
\hline & Drought + nutrients & Mittler and Blumwald, 2010 \\
\hline & Drought + high light & Carvalho et al., 2016 \\
\hline & Heat + ozone & Pliūra et al., 2019 \\
\hline & Heat + salinity & Suzuki et al., 2016b \\
\hline & Heat + pathogen & Pandey et al., 2017 \\
\hline & Heat + pets & Nguyen et al., 2016 \\
\hline & Heat + UV & Mittler and Blumwald, 2010 \\
\hline & Heat + high light & Carvalho et al., 2016 \\
\hline & Salinity + ozone & Peykanpour et al., 2016 \\
\hline & Salinity + pathogen & Bai et al., 2018 \\
\hline & Salinity + nutrients & Suzuki et al., 2014 \\
\hline & Chilling + high light & Terada et al., 2018 \\
\hline & Pathogen + nutrients & Mittler and Blumwald, 2010 \\
\hline \multirow[t]{7}{*}{ Positive combination } & Drought ozone & $\begin{array}{l}\text { Mittler and Blumwald, } \\
\text { 2010; Suzuki et al., } 2014\end{array}$ \\
\hline & Drought + high $\mathrm{CO}_{2}$ & van der Kooi et al., 2016 \\
\hline & Salinity + high $\mathrm{CO}_{2}$ & Sgherri et al., 2017 \\
\hline & Ozone + pathogen & Mittler and Blumwald, 2010 \\
\hline & Ozone + high $\mathrm{CO}_{2}$ & Ainsworth, 2008 \\
\hline & Pathogen + UV & $\begin{array}{l}\text { Mittler and Blumwald, } \\
\text { 2010; Suzuki et al., } 2014\end{array}$ \\
\hline & High $\mathrm{CO}_{2}+$ high light & $\begin{array}{l}\text { Mittler and Blumwald, } \\
\text { 2010; Suzuki et al., } 2014\end{array}$ \\
\hline
\end{tabular}

salinity, salinity and heat, and drought and extreme temperatures due to climate change are expected to occur in many agricultural areas across the globe (Table 1; Suzuki et al., 2014; Wijewardene et al., 2020). On the other hand, the behavior of some arthropod pests may also be influenced by climate changes and abiotic stresses (Nguyen et al., 2016; Bonnet et al., 2017). Copolovici et al. (2014) reported that changes in plant metabolic processes driven by abiotic stress can affect the response of plants to attack generated by arthropod pest herbivory.

As a result of climate change, the most limiting abiotic factors for crop productivity and food security are drought and heat (Fahad et al., 2017; Hussain et al., 2019). Studies on the effect of drought and heat on plant cultivation have been widely documented (Zhou et al., 2017; Guo et al., 2018; Haworth et al., 2018; Osmolovskaya et al., 2018). However, research on the combination of heat stress and drought is not common even though these two types of abiotic stresses usually appear simultaneously under field conditions and generate harmful effects on crop growth and productivity (Table 1; Suzuki et al., 2014; Raja et al., 2020). The combination of water deficit (drought) and heat (increases in average air temperature above the optimum) stresses can alter physiological, biochemical, and molecular processes in plants (Prasad et al., 2008; Lamaoui et al., 2018).

In general, the combination of drought and high daytime temperatures reduces the photosynthetic efficiency, stomatal conductance, leaf area, water use efficiency (WUE), and yield of plants (Sattar et al., 2020). The effect of the combination between drought and heat has been reported in some crops of agricultural interest such as lentil (Lens culinaris Medikus; Sehgal et al., 2017), chickpea (Cicer arietinum L.; Awasthi et al., 2014), tomato (Solanum lycopersicum L.; Zhou et al., 2017), wheat (Triticum aestivum L.; Liu et al., 2018), Jatropha curcas L. (Silva et al., 2010), and citrus trees (Zandalinas et al., 2017). These reports show that the combined effect of drought and heat on plant growth and productivity is more severe than the individual effects of these factors (Awasthi et al., 2014; Urban et al., 2018).

Plants are subject to the herbivory of a wide range of phytophagous arthropods during their growth and development; therefore, this factor is one of the main types of biotic stress affecting crop growth (Zhou et al., 2015; Bonnet et al., 2017). Several studies indicate that environmental stresses, such as drought or high temperatures, can make plants more susceptible to arthropod feeding and attack because of a drop in plant defense mechanism (DeLucia et al., 2012; Gutbrodt et al., 2012; Weldegergis et al., 2015; Havko et al., 2020; Table 1). The combination of the effects of drought or high temperatures and the presence of herbivorous arthropods has been investigated in plants such as mountain Avens (Dryas octopetala; Birkemoe et al., 2016), tomato (Havko et al., 2020), arabidopsis (Arabidopsis thaliana L.; Davila Olivas et al., 2016), apple (Malus $x$ domestica Borkh.; Gutbrodt et al., 2012), and bittersweet nightshade (Solanum dulcamara L.; Nguyen et al., 2016).

Maize (Zea mays L.), along with wheat and rice, is one of the main staple foods in the world with a global production of more than $1 \times 10^{9} t$ since 2013 (Noman et al., 2015; Zampieri 
et al., 2019). Maize is grown for various purposes, such as human consumption, animal feed, forage production, and renewable energy (bioenergy; Aslam et al., 2015; Ai and Jane, 2016). In many regions of the world, maize is commonly grown in semi-arid environments characterized by low water availability and high daytime temperatures, two environmental factors that usually occur simultaneously in the field ( $\mathrm{Hu}$ et al., 2015; Zhao et al., 2016). Maize crops are extremely sensitive to heat and drought stresses (Zhao et al., 2016). According to Hussain et al. (2019), world maize yield and production are projected to decline by 15-20\% per year due to heat and drought conditions, with these two factors becoming major threats to this crop. On the other hand, a reduction in maize yield of $6-19 \%$ caused by arthropods and other herbivores has also been reported (Block et al., 2019). Rachiplusia nu (Guennée; Lepidoptera: Noctuidae; Russo et al., 2019), fall armyworm [Spodoptera frugiperda (JE Smith; Lepidoptera: Noctuidae)] (Pannuti et al., 2016), black cutworm [Agrotis ípsilon (Hufnagel; Lepidoptera: Noctuidae)] (Yan et al., 2020), cotton bollworm [Helicoverpa armígera (Hübner; Lepidoptera: Noctuidae)] (Gomes et al., 2017), corn earworm [Helicoverpa zea (Boddie; Lepidoptera: Noctuidae)], and thrips [Frankliniella williamsi (Thysanoptera: Thripidae)] (Manandhar and Wright, 2016) are some of the main pests reported for this crop.

The results of studies on the responses and adaptations of maize plants exposed to abiotic and biotic stresses have been well documented separately (Zhao et al., 2016; Block et al., 2019). However, the information available remains limited to physiological responses of maize plants exposed to the combination of multiple abiotic and biotic stress factors, such as drought, high temperature and arthropod pest herbivory. Therefore, more studies are necessary to continue understanding the effects of these multiple combinations. Due to the complexity of the combinations of drought, heat, and arthropod pests, this review aimed to report the effects of the combination of abiotic (drought and heat) and biotic (herbivory) stresses on the physiological, biochemical, and molecular mechanisms of maize plants.

\section{PHYSIOLOGICAL RESPONSES TO THE COMBINATION OF HEAT AND DROUGHT STRESS IN MAIZE}

Plant responses to the combination of drought and heat depend on the intensity, frequency, and duration of the interaction between both stresses, as well as the stage of phenological development of the crop (Prasad et al., 2008; Fahad et al., 2017). The individual and combined effects of drought and heat on the physiological response of maize plants have been widely documented, which are summarized in Table 2. The combined effects of these two environmental stresses have a greater negative impact on plant growth compared to the effect of each individual factor (Killi et al., 2017; Hussain et al., 2019).

The physiological responses of maize plants to drought and heat can be classified into three different mechanisms: escape, avoidance, and tolerance (Figure 1). In the escape mechanism, the plant tries to complete the reproductive stage before the stress became more severe (Aslam et al., 2015; Khan et al., 2019). Avoidance mechanisms are mainly morphological and physiological changes that allow reducing exposure to the combination of drought and heat (Figure 1; Zhang et al., 2016; Lamaoui et al., 2018). Avoidance of drought or heat stress damage can be achieved by increasing root system to maintain water uptake (Aslam et al., 2015). Also, the effects of any of the two stresses can be avoided by changing plant architecture. Some of these changes may include a lower leaf angle, reduced leaf rolling, compact tassel, and efficient cuticle wax biosynthesis to reduce direct sunlight exposure and evapotranspiration rates (Aslam et al., 2015; Tiwari and Yadav, 2019), and reduced leaf stomatal number and conductance to avoid water losses to keep water status (Figure 1; Aslam et al., 2015; Lamaoui et al., 2018). Finally, tolerance to the combination of heat and drought stress is the ability to keep growth and development through cellular and biochemical modifications. These changes include the accumulation of compatible osmolytes [proline, glycine betaine, soluble sugars, and inorganic ions $\left(\mathrm{K}^{+}, \mathrm{Na}^{+}, \mathrm{Ca}^{2+}\right.$, $\mathrm{Mg}^{2+}, \mathrm{Cl}^{-}$, and $\left.\left.\mathrm{NO}_{3}^{-}\right)\right]$to support plant water status through osmotic adjustment (Blum, 2017; Lamaoui et al., 2018) and the activation of the enzymatic and non-enzymatic antioxidant system [superoxide dismutase (SOD), catalase (CAT), peroxidase (POD), and ascorbate peroxidase (APX)] (Aslam et al., 2015; Hussain et al., 2019) and growth regulators (plant hormones) such as abscisic acid (ABA; Aslam et al., 2015; Lamaoui et al., 2018). Other modifications also include the activation of transcription factors (TFs) that regulate expression levels of genes sensitive to the combination of drought and high temperatures (Lamaoui et al., 2018) and the overexpression of stress proteins such as heat shock proteins (HSP), late embryogenesis abundant (LEA) proteins, and aquaporins (that intervene in the movement of water under stress; Figure 1; Khan et al., 2019; Tiwari and Yadav, 2019).

In maize, the combination of drought and heat reduces the photosynthetic rate, stomatal conductance, leaf area, and WUE (Sehgal et al., 2017). Plant water status parameters such as relative water content (RWC), leaf water potential $\left(\Psi_{h}\right)$, osmotic potential $\left(\Psi_{s}\right)$, and turgor potential $\left(\Psi_{t}\right)$ decrease progressively under drought and exposure to high temperatures $\left(>35^{\circ}\right.$; Shah and Paulsen, 2003). Hussain et al. (2019) reported a greater reduction in RWC values in two maize hybrids subjected to the combination of drought and heat, compared to the individual effects of each abiotic stress. Under water shortage, root hydraulic conductivity can be reduced to avoid water losses in the plant. This effect can be more severe under heat stress, causing roots damage (Lamaoui et al., 2018).

Photosynthesis in C4 plants is more sensitive to drought periods due to stomatal closure and the reduction in the activity of photosynthetic enzymes compared to C3 plants (Ghannoum, 2009; Lipiec et al., 2013). Under thermal stress, photosynthesis in $\mathrm{C} 4$ plants shows a greater tolerance than in plants with C3 metabolism, associated with the accumulation of oxaloacetic acid within the bundle sheath cells. This process effectively concentrates $\mathrm{CO}_{2}$ at the carboxylation site of Rubisco, 
TABLE 2 | Summary of the impact of heat and drought stress (individual or in combination) on the physiological responses of maize (Zea mays L.) plants.

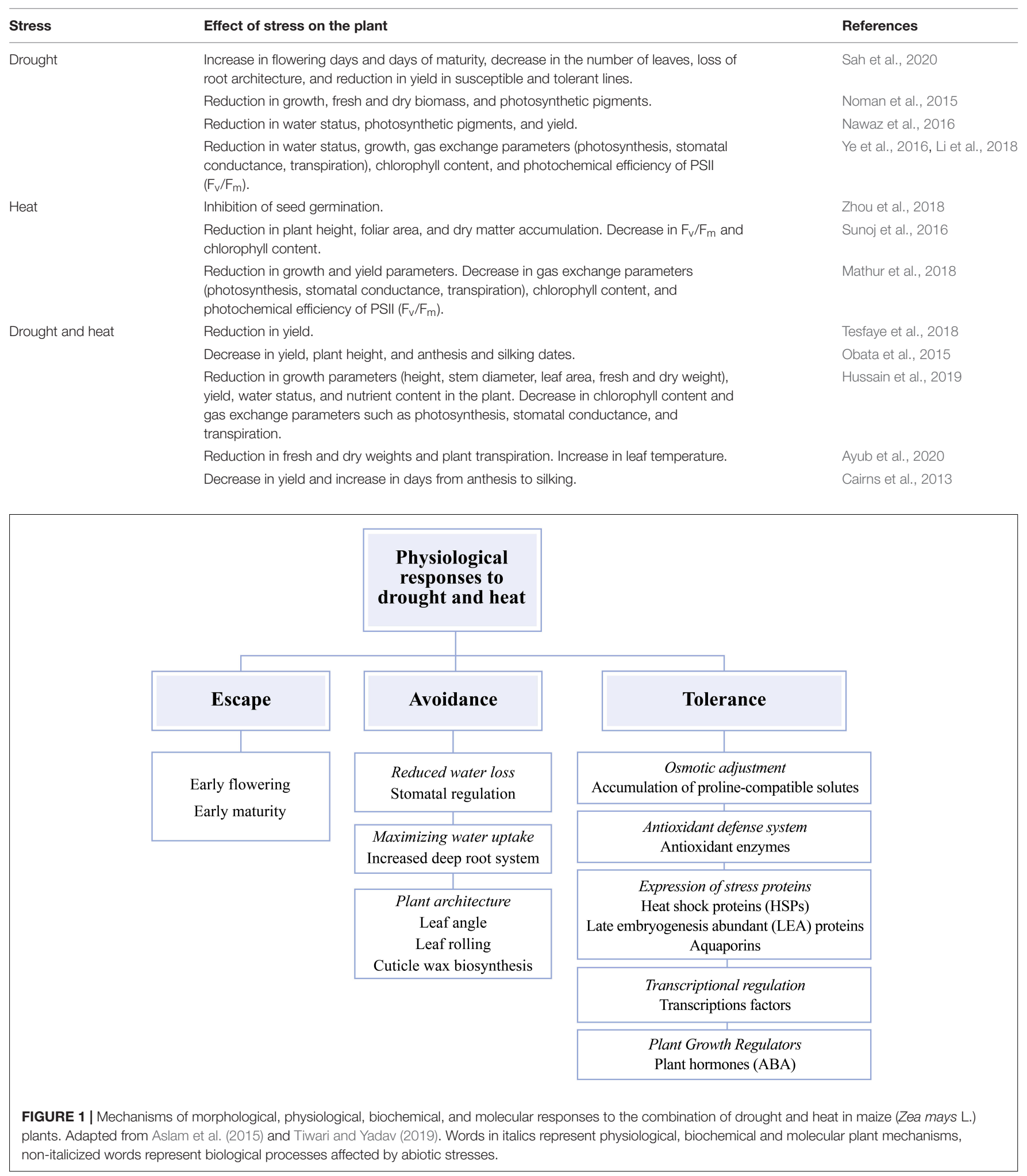

suppressing photorespiration (Killi et al., 2017,2020). Water scarcity is known to affect the electron transport chain through inhibition of D1 synthesis and damages to the oxygen-evolving complex in the PSII and in the reaction centers of both PSII and PSI (Dalal and Tripathy, 2018; Wang et al., 2018). Also, water deficit reduces the abundance of proteins involved in 
Calvin-Benson-Bassham cycle, such as ribulose 1,5-bisphosphate carboxylase (RuBisCO), Fructose 1,6-bisphosphate aldolase, triosephosphate isomerase, and glyceraldehyde phosphate dehydrogenase A (Burgess and Huang, 2016; Dalal and Tripathy, 2018). On the order hand, heat stress affects photosynthesis since it could cause a lesion on the thylakoid membranes (Ivanov et al., 2017), directly damage the photosynthetic apparatus, such as the PSI and PSII reaction centers, and in the cytochrome b6f (Cytb6f) complex, and decrease the activity of Rubisco (Hu et al., 2020). Perdomo et al. (2017) found a decrease in the Rubisco activity and the electron transport rate in maize plants subject to drought and high daytime temperatures evaluated individually.

Photosynthesis rate is extremely sensitive to the combination of heat and drought stresses (Perdomo et al., 2015). This sensitivity can be a consequence of the stomatal closure induced by the combination of these stresses, but it can also be attributed to non-stomatal limitations such as decreased leaf expansion, lower content of photosynthetic pigments, and inadequate functioning of the photosynthetic machinery (Fahad et al., 2017; Lamaoui et al., 2018). Hussain et al. (2019) observed a decrease in the photosynthetic rate of two maize hybrids; this drop is associated with the reduction in the total chlorophyll content and stomatal conductance values under the combination of drought and heat. Under high daytime temperatures, C4 plants, such as maize, open stomata to cool leaves by increasing the transpiration rate (Perdomo et al., 2015). However, the combination with drought generates a reduction in the values of stomatal conductance and transpiration in the same species (Hussain et al., 2019; Sabagh et al., 2020).

Regarding the phytochemical machinery, the activity of PSII and its maximum quantum efficiency $\left(\mathrm{F}_{\mathrm{v}} / \mathrm{F}_{\mathrm{m}}\right)$ decrease after exposure to the combination of drought and heat (Alhaithloul, 2019). Killi et al. (2017) recorded a reduction in the $F_{V} / F_{m}$ ratio and actual quantum yield of PSII (ФPSII), and an increase in non-photochemical quenching in two maize varieties that are susceptible and tolerant to drought when subjected to the combination of high temperatures and drought stress. These responses may also be associated with the disturbance of the integrity and fluidity of thylakoid membranes, and inhibition of electron transfer due to oxidative stress damage in the plant (Tian et al., 2013; Mathur et al., 2014; Talaat, 2020). Chlorophyll $a$ fluorescence (an indicator of PSII performance) has been used as a quantitative measure of the impact of drought and heat on the functionality of thylakoid membranes in crops (Sehgal et al., 2017; Killi et al., 2020).

The reproductive stage is more sensitive to the combination of drought and heat than the vegetative stages (Obata et al., 2015; Sehgal et al., 2017). The reproductive processes most susceptible to the combination of heat and drought stress are pollen and stigma viability, pollen tube growth, early embryo development, flowering and seed filling, and number of kernels (Zandalinas et al., 2017; Lamaoui et al., 2018; Sehgal et al., 2019). Shah and Paulsen (2003) reported that stress during the reproductive phase also induces the abortion of kernels, possibly by decreasing the supply of carbohydrates and negatively affecting plant yield. In maize plants subjected to heat stress and drought, yield parameters such as kernels.ear ${ }^{-1}$, 100-kernel weight, kernel yield.plant ${ }^{-1}$, and harvest index were significantly reduced (Hussain et al., 2019).

\section{BIOCHEMICAL AND MOLECULAR RESPONSES TO THE COMBINATION OF HEAT AND DROUGHT STRESS IN MAIZE}

The genes expression related to water channel proteins and ion transporters is a combined strategy to reduce the impact generated by environmental stress factors (Afzal et al., 2016; Kido et al., 2019). These strategies also rely on genes related to the protection of membranes and essential proteins such as chaperones, HSP and osmoprotectant osmolytes (Bandyopadhyay et al., 2019; Kido et al., 2019). The accumulation of compatible osmolytes in plants subjected to stress due to drought, heat and their combination has been linked to the protection of protein structures and the stabilization of cell membranes to restore homeostasis (Lamaoui et al., 2018). The main osmoprotectants are those derived from polyamines, amino acids, soluble carbohydrates (e.g., glucose), betaines (e.g., glycine betaine), and sugar alcohols (Lamaoui et al., 2018; Kido et al., 2019). Proline is one of the most studied osmolytes under water deficit and heat stresses periods. It is a proteinogenic amino acid involved as an osmoprotectant of membranes and proteins. Proline also generates scavenging of reactive oxygen species (ROS) and is considered a compatible osmolyte for the osmotic adjustment of cells (Zouari et al., 2019; Zulfiqar et al., 2020). Ayub et al. (2020) reported the accumulation of proline and total soluble sugars in four maize hybrids subjected to the combination of drought and high temperatures. The proline synthesis and accumulation have been used as a tolerance trait to abiotic stresses (Lamaoui et al., 2018).

Another tolerance mechanism that plants have to adapt to heat and drought stresses is the induction of antioxidant enzymes such as CAT, glutathione peroxidase, total superoxide dismutase (T-SOD), POD, APX, and glutathione reductase (GR). Additionally, plants induce non-enzymatic antioxidants such as glutathione (GSH) and ascorbate to control ROS concentration (Zandalinas et al., 2017). In maize, lower concentrations of ROS [as superoxide anion $\left(\mathrm{O}_{2}^{-}\right)$, hydrogen peroxide $\left(\mathrm{H}_{2} \mathrm{O}_{2}\right)$, and hydroxyl free radical $\left.\left(\mathrm{OH}^{-}\right)\right]$and malondialdehyde (as a by-product of lipid peroxidation) have been reported with the increase in the activity of enzymatic antioxidants such as T-SOD and POD, and non-enzymatic antioxidants such as GSH in two maize materials under the combination of drought and heat (Hussain et al., 2019).

Plant hormones are also involved in the regulation of tolerance to environmental stresses (drought and heat; Lamaoui et al., 2018). ABA is the most important plant hormone that intervenes in the regulation of plant acclimation to drought and heat (Zandalinas et al., 2017). The increase in ABA accumulation is also associated with tolerance to the combination of heat and drought since it regulates stomatal opening and closure, and activates antioxidant defense systems. It also stimulates the production of dehydrins and LEA proteins that participate 
in osmotic adjustment and other plant protection mechanisms (Haider et al., 2018; Lamaoui et al., 2018; Zhang et al., 2019). However, the previous responses mediated by the endogenous accumulation of ABA are associated with plant tolerance to the abiotic stress factor studied individually and not in combination (Hu et al., 2010). In maize, an endogenous accumulation of ABA has been reported in two cultivars (tolerant and sensitive to drought) after 12 days of exposure to drought (Zhang et al., 2012). Also, Cheikh and Jones (1994) reported an increase in ABA levels in the female inflorescence (ear) of maize plants exposed to a temperature of $35^{\circ} \mathrm{C}$ for 8 days. Plant hormones such as cytokinins and auxins play an important role in responses to abiotic stress (Bielach et al., 2017). These hormones are related to the stimulation of cell division and the control of plant growth and development. Additionally, their ability to crosstalk promotes adaptive responses to different types of stress (Dobra et al., 2010; Bielach et al., 2017). For example, Bedada et al. (2016) reported an increase in endogenous levels of cytokinins through the expression of IPT genes that encode the activity of the enzyme isopentenyltransferase. This enzyme catalyzes the synthesis of cytokinins, which may be related to an increase in tolerance to water deficit in maize plants.

Cell molecular events can be affected by environmental stresses (Aslam et al., 2015; Guo et al., 2016). Plant survival strategies under drought and high daytime temperatures periods occur through the modification of gene expression, which results in the generation of certain proteins known as stress proteins (Aslam et al., 2015; Shafqat et al., 2021). Water channel proteins such as aquaporins (AQP), LEA, and HSP are some of the proteins that play an important role in plant tolerance to stress caused by drought, heat, and their combination (Priya et al., 2019). AQP are integral proteins found in tonoplasts, plasma membranes, and other intracellular membranes that are abundantly expressed in roots (Shafqat et al., 2021). Under water shortage, they preserve cell homeostasis by preventing water loss and increase membrane permeability. AQP also play a role in maintaining the WUE and signaling at the whole plant level by interacting with ROS in response to external signals (Aslam et al., 2015; Priya et al., 2019). Tonoplast intrinsic proteins, membrane intrinsic proteins, nodulin-like proteins (NIP), and plasma membrane intrinsic proteins (PIP) are subfamilies of AQP that promote water transport and tolerance to water and heat stress in maize plants (Aslam et al., 2015; Hu et al., 2015). Hu et al. (2015) found that aquaporin PIP2-7 and the integral membrane protein of NIP type showed a positive regulation under the combination of drought and heat in maize plants.

Under combined stresses (water deficit and high daytime temperatures), it is possible for plants to induce the transcription of proteins related to cell protection against dehydration (Nagaraju et al., 2019). LEA are some of the proteins involved in resistance to environmental stresses, mainly drought, as they accumulate in stressed tissues (Magwanga et al., 2018). They can also act as chaperones, preventing dehydration in some developmental stages susceptible to water limitation such as seed, pollen grain, shoot, and root development under drought (Pedrosa et al., 2015; Kaur and Asthir, 2017). Li and Cao (2016) identified a total of 32 genes related to LEA proteins in maize plants subjected to drought stress.

The expression of HSP is an adaptation strategy to combined stresses (drought and heat), and their accumulation correlates with stress tolerance in plants (Grigorova et al., 2011; Lamaoui et al., 2018). HSP act as molecular chaperones, preventing the aggregation of denatured proteins, stabilizing membrane proteins, facilitating protein folding, and allowing the renewal of normal cellular and physiological activities which contribute to a higher level of tolerance to stress (Priya et al., 2019; Khan and Shahwar, 2020). In maize plants, two types of HSP families, HSP90 and HSP100, have been reported in response to drought stress. These two families are located in the cytosol, nucleus and endoplasmic reticulum of the cell and have role in the translocation of proteins, regulation of steroid hormone receptors, and folding of proteins (Khan and Shahwar, 2020). Hu et al. (2010) found a strong correlation between the accumulation of proteins sHSP17.2, sHSP17.4, and sHSP26 and tolerance of the whole plant to the combination of drought and heat. Hussain et al. (2019) also reported a greater accumulation of HSP in two maize hybrids subjected to the combination of drought and high temperatures.

Drought and heat also generate changes in the cell plasma membrane, damaging the permeability of this cell structure (ElBasyoni et al., 2017). Damage to cell membrane permeability due to these abiotic stress conditions may be caused by membrane protein denaturation and enzyme inactivation, and results in the cell being unable to maintain its organic composition (ElBasyoni et al., 2017; Nijabat et al., 2020). The alteration in the permeability and integrity of the cell membrane generates a lower ion flow and higher electrolyte leakage. It also causes imbalances in the RWC, increases in the production of toxic compounds, and alterations of homeostasis. These changes inhibit cell viability, which is reflected in lower growth and development of plants exposed to drought and high daytime temperatures (Alhaithloul, 2019; Nijabat et al., 2020). Electrolyte leakage is a technique that has been used to evaluate cell membrane stability as a mechanism of tolerance to heat and drought stresses (Bajji et al., 2002; Ilík et al., 2018). Increased cell membrane damage expressed as higher electrolyte leakage has been reported in maize plants subjected to drought (Chen et al., 2010) and high daytime temperatures (Takele, 2010).

The TFs responsive to stress are the main cellular mechanisms related to plant tolerance to environmental adverse conditions (Zandalinas et al., 2017). TFs have been isolated from different genes related to abiotic stress and can regulate various complex pathways by modifying metabolite fluxes to improve stress tolerance (Aslam et al., 2015; Lamaoui et al., 2018). The main families of stress-related TFs include DREB, ERF, WRKY, MYB, bHLH, bZIP, DOF, and NAC (Lamaoui et al., 2018). Shi et al. (2017) observed that overexpression of the ZmARGOS1 gene in maize plants improved tolerance to drought. The overexpression of OsMYB55 in maize plants has led to an increase in the tolerance to the combination of drought and heat, which resulted in better growth and yield of plants under this environmental interaction (Casaretto et al., 2016). 


\section{MAIZE PLANT RESPONSES TO ARTHROPOD HERBIVORY}

Plants and arthropods have coevolved for more than 350 million years (Zhu et al., 2014). Arthropods have evolved to be able to locate host plants and oviposit using physical and chemical cues from those plants (Wu and Baldwin, 2010). Arthropod herbivory is a major biotic stress under natural conditions. For this reason, plants have developed different types of defenses, such as constitutive and inducible defenses, to resist or reduce the effects of arthropod attacks (Bonnet et al., 2017).

The plant has two defense strategies against herbivory attack: (i) resistance, which occurs when the plant prevents arthropod herbivores from feeding, and (ii) tolerance, which occurs when plant traits reduce the negative effect of herbivore damage (Gatehouse, 2002; Mitchell et al., 2016). One of the traits or responses related to crop resistance to arthropod herbivory is the chemical deterrence of pest settling and feeding (Mitchell et al., 2016). The deterrence of herbivore feeding is caused by the mixture of volatile and non-volatile compounds (War et al., 2012). Herbivore induced plant volatiles play an important role in defending the plant against the attack of arthropod pests by attracting the natural enemies of arthropod herbivores and acting as deterrents of their feeding and/or oviposition (War et al., 2012; Mitchell et al., 2016). The most common volatiles are green leaf volatiles (aldehydes, alcohols, and esters), aromatic compounds, and terpenes (Qi et al., 2018). In maize, aromatic compounds such as indole and methyl salicylate have been detected reducing the consumption and oviposition of arthropod herbivores (Qi et al., 2018). Ortiz-Carreon et al. (2019) identified the emission of three types of volatiles ( $\alpha$-pinene, $\alpha$-longipinene, and $\alpha$-copaene) after the damage of $S$. frugiperda larvae. Additionally, the emissions of these compounds attracted females of the endoparasitoid Chelonus insularis Cresson (Hymenoptera: Braconidae).

Structural traits of the plant such as trichomes, spines, waxy cuticles, or sclerophylly, can play the role of physical barriers to prevent the attachment, feeding and/or oviposition of arthropod pests (Santamaria et al., 2013). Trichome density and plant cuticle are the most studied traits in crop protection (Mitchell et al., 2016). Trichomes can prevent the attachment of arthropod pests and decrease their movement in crops (Andama et al., 2020). Trichomes also play a role in the interaction between plants and abiotic stresses, reducing heat loss from plants and increasing plant resistance to drought damage (Zhang et al., 2020). On the other hand, cuticular waxes can form slippery films or crystals that impede the attachment of pests to the plant surface (Mitchell et al., 2016). Additionally, wax deposition has also been reported as a plant response to abiotic stress, since it is considered a tolerance trait to drought and heat (Dhanyalakshmi et al., 2019). Moya-Raygoza (2016) recorded less damage in the teosinte Zea perennis (Hitchc.) and Zea mays ssp. parviglumis (H. H. Iltis \& Doebley) caused by $S$. frugiperda (Lepidoptera: Noctuidae) when a higher density of trichomes was found in the upper leaf blade.

Another plant mechanism of response to the attack of arthropod herbivores is reducing plant palatability through the production of compounds that are toxic or harmful to the intestinal function of arthropods (War et al., 2012). The compounds that have been studied the most are alkaloids, benzoxazinoids, and terpenoids (Mithöfer and Boland, 2012). Benzoxazinoids are a group of compounds that play a defensive role in maize plants against arthropod herbivores (Qi et al., 2018). Yan et al. (1999) demonstrated that DIMBOA (2,4-dihydroxy7-metoxy-1,4-benzoxazin-3-one), a benzoxazinoid metabolite, is toxic to the Asian corn borer [Ostrinia furnacalis (Guenée); Lepidoptera: Crambidae]. Maize plants have been shown to have a defense system against the attack of Spodoptera littoralis and S. frugiperda. This defense system consists of the accumulation and emission of HDMBOA (2-hydroxy-4, 7-dimetoxy-1, 4benzoxazin-3-one), which is a toxic compound for these both herbivorous arthropods (Glauser et al., 2011).

The mechanisms of tolerance to biotic stress by herbivory are related to the alteration of physiological processes such as photosynthetic activity and growth, the plant phenological stage, and the use of nutrients stored in the plant (Mitchell et al., 2016). Partial defoliation due to arthropod herbivory can lead to an increase in the photosynthetic rate in the remaining tissues (Redondo-Gómez, 2013; Mitchell et al., 2016). A higher supply of leaf or root cytokinins due to partial defoliation can increase $\mathrm{CO}_{2}$ fixation and nutrient transport and assimilation (Redondo-Gómez, 2013). Additionally, there may be increases in the production of the Rubisco enzyme and the chlorophyll content of the remaining leaf tissue, which could improve the photosynthetic rate (Turnbull et al., 2007; Redondo-Gómez, 2013). Mitchell et al. (2016) mentions the activation of dormant buds after damage to reproductive or vegetative meristems as a tolerance mechanism that allows the plant to recover from the attack of arthropod herbivores. In maize plants, the delay in the allocation of resources (carbohydrates and nutrients) can generate tolerance to the attack of the western corn rootworm (Diabrotica virgifera virgifera LeConte; Coleoptera: Chrysomelidae; Robert et al., 2015).

\section{RESPONSES OF MAIZE PLANTS TO THE COMBINATION BETWEEN DROUGHT OR HIGH TEMPERATURES AND ARTHROPOD HERBIVORY}

Climate models predict a continuous increase in temperature and greater rainfall variability, with increments in drought and extreme temperature periods in the future (Gutbrodt et al., 2012; Grinnan et al., 2013). Global climate change is expected to affect the interaction between arthropods and plants through alterations in the physiology, behavior, and life cycle parameters of arthropod pests, and morphological, physiological, and biochemical changes in host plants (Cornelissen, 2011). Increases in temperatures are highly correlated with changes in phenology, distributions, abundance, and interactions between species and help to improve arthropod survival during extreme environments (Grinnan et al., 2013; Bansal, 2015). On the other hand, water shortage episodes can generate negative or positive effects on herbivore populations, depending on the 
intensity and frequency of stress (Bansal, 2015). Drought periods are associated with high temperatures that can accelerate the metabolism of insects, increasing their growth rate, consumption, and development (Neven, 2000; Bansal, 2015). Loss of turgor due to severe drought conditions could limit the availability of nitrogen-containing compounds for arthropods that feed on sap, reducing their performance (Gely et al., 2020).

Increases in temperature and drought can cause more frequent and severe outbreaks of herbivorous arthropod populations (Grinnan et al., 2013). These environmental stresses can cause a reduction in plant defense compounds against arthropods. The drop in these compounds increases the availability of nitrogen and proteins which can lead to more palatable food for some herbivorous arthropods (Gutbrodt et al., 2011). The synergistic combination between environmental stresses (drought or heat) and the increase in arthropod pest populations could lead to a reduction in plant yield (Grinnan et al., 2013). On the other hand, water deficit can cause an increase in the concentrations of secondary metabolites in some plant species, limiting the performance of herbivorous arthropods (Nguyen et al., 2018). Exposure to multiple environmental and biotic stress factors (arthropods) can have interactive effects on secondary metabolites such as volatile or non-volatile compounds since they share metabolic pathways with hormones such as jasmonic acid and salicylic acid (Scott et al., 2019).
Copolovici et al. (2014) observed an interactive response between drought and herbivory mediated by methyl salicylate (derived from salicylic acid), resulting in a faster emission of compounds such as $\beta$-ocimene and 4,8-dimethyl-1,3,7-nonatriene (DMNT) in drought-stressed plants.

The accumulation of non-protein amino acids such as 5-hydroxynorvaline under herbivory and drought has been observed in maize (Yan et al., 2015). These types of compounds are defense metabolites to protect the plant against arthropod herbivores due to their poor incorporation during protein synthesis and/or the inhibition of biosynthetic pathways in primary metabolism (Huang et al., 2011). The accumulation of 5-hydroxynorvaline has been reported during the herbivory of corn leaf aphids (Rhopalosiphum maidis) and beet armyworm (Spodoptera exigua; Yan et al., 2015). These same authors observed a greater accumulation of non-protein amino acid 5-hydroxynorvaline under water deficit in plants under the herbivory of the corn leaf aphid and beet armyworm. The inhibition mainly of the aphid's reproduction indicates that this secondary metabolite can have a defense function in maize plants (Yan et al., 2015). On the other hand, the accumulation of antimicrobial compounds of low molecular weight (terpenoid phytoalexins) has also been reported in response to the combination of biotic and abiotic factors in plants (Schmelz et al., 2014). In maize, two new families of

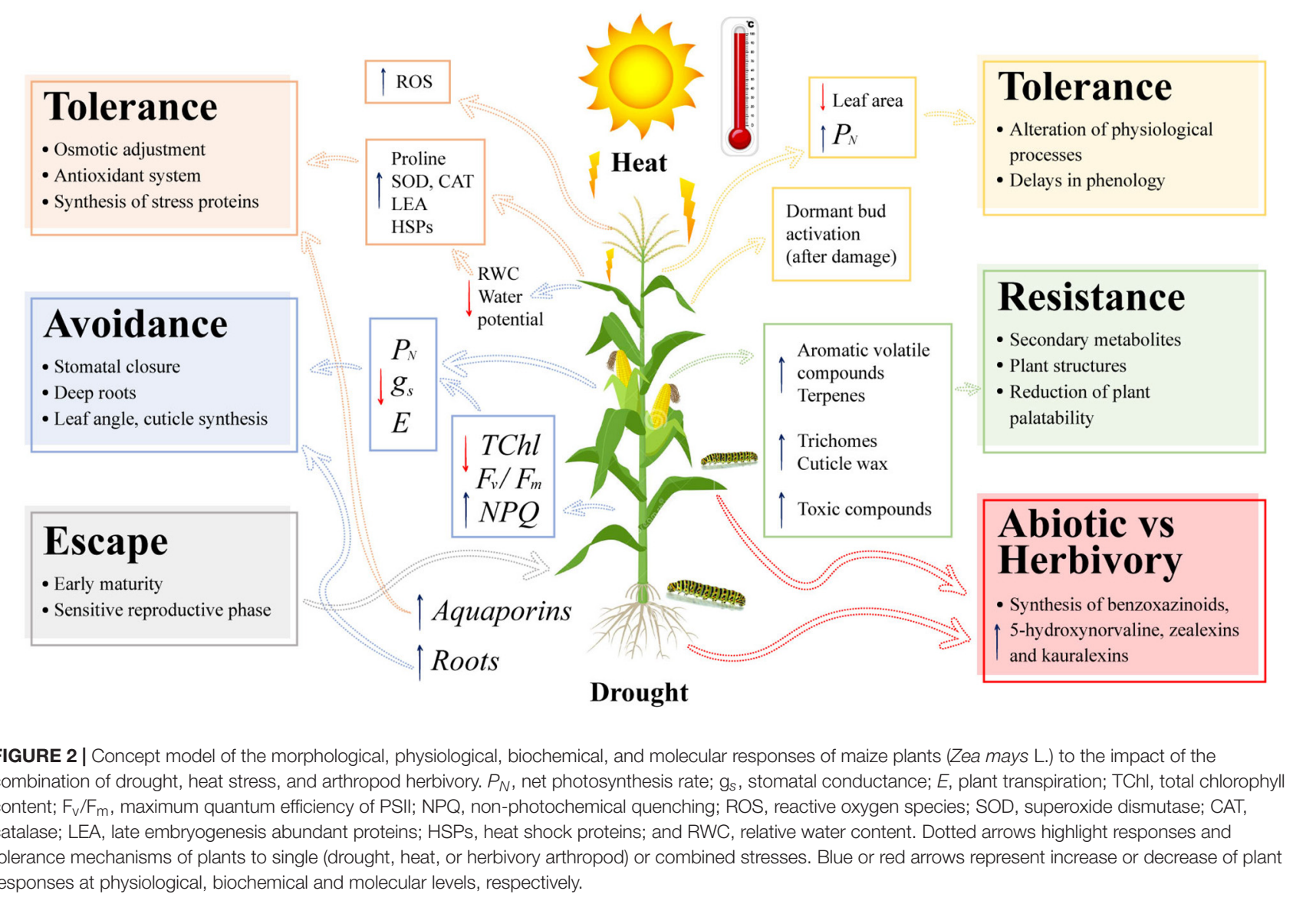


terpenoid phytoalexins, zealexins, and kauralexins have been identified. These families show high antifungal and anti-feedant activity for insects; however, little is known about their role in responses to abiotic factors (Block et al., 2019). The accumulation of phytoalexins, mainly in roots, may be mediated by $\mathrm{ABA}$ signaling (Yang et al., 2012). Vaughan et al. (2015) showed a greater accumulation of zealexins and kauralexins (non-volatile terpenoid compounds) in maize roots exposed to herbivory by Diabrotica balteata under water shortage. The production of zealexins and kauralexins in plants is a defense response to biotic stresses that affects directly the growth and reproduction of arthropod pests in maize crops (Block et al., 2019). Finally, the benzoxazinoids production has also been reported as one of the main metabolites of direct defense in maize plants under drought, insect herbivory, or their combination. These stress factors favor the accumulation of benzoxazinoids through the systemic signaling of ABA (Vaughan et al., 2015).

\section{CONCLUSION AND FUTURE PERSPECTIVES}

Plants face the combination of different types of abiotic and biotic stresses. The physiological, biochemical, and molecular responses of maize plants to drought, high daytime temperatures, and the effect on some arthropod herbivores are summarized in a concept model (Figure 2). Maize plants show a wide range of responses to drought and heat that generate alterations in plant growth and morphology. Plants have developed different strategies to survive under hot and dry environments. Escape, avoidance, and tolerance are the mechanisms that work under the combination of these two environmental stresses (Figure 2).

Early maturation, changes in stomatal regulation, root system, and plant architecture constitute the responses related to escape and avoidance. A decrease in photosynthesis associated with stomatal closure, low plant water content, low photochemical activity of PSII, and degradation of photosynthetic pigments are responses to the combination of drought and heat, with the reproductive phase being the most sensitive to this combination. Tolerance is regulated by biochemical and molecular mechanisms such as compatible osmolyte synthesis,

\section{REFERENCES}

Afzal, Z., Howton, T. C., Sun, Y., and Mukhtar, M. S. (2016). The roles of aquaporins in plant stress responses. J. Dev. Biol. 4:9. doi: 10.3390/jdb4010009

Ahmad, B., Raina, A., and Khan, S. (2019). "Impact of biotic and abiotic stresses on plants, and their responses," in Disease Resistance in Crop Plants, ed. S. Wani (Cham: Springer), 1-20. doi: 10.1007/978-3-030-20728-1_1

Ai, Y., and Jane, J. L. (2016). Macronutrients in corn and human nutrition. Comp. Rev. Food Sci. F 15, 581-598. doi: 10.1111/1541-4337.12192

Ainsworth, E. A. (2008). Rice production in a changing climate: a meta-analysis of responses to elevated carbon dioxide and elevated ozone concentration. Glob. Change Biol. 14, 1642-1650. doi: 10.1111/j.1365-2486.2008.01594.x

Alhaithloul, H. A. S. (2019). Impact of combined heat and drought stress on the potential growth responses of the desert grass artemisia sieberi alba: relation to biochemical and molecular adaptation. Plants 8:416. doi: 10.3390/ plants 8100416 increased enzymatic activity, accumulation of plant growth regulators, increased expression of water transporting and stress proteins, and TFs (Figure 2). The presence of arthropod herbivores generates resistance responses in maize plants, such as synthesis of volatile and non-volatile compounds, structural traits such as trichomes and cuticle waxes, and the production of toxic compounds such as benzoxazinoids. Tolerance traits to arthropod herbivory are related to an improvement in the photosynthetic efficiency and regulation of the plant's phenological cycle. Finally, the combination of environmental stresses and arthropod herbivory in maize plants can increase the production of secondary metabolites such as volatile and nonvolatile compounds, improving the defense response of maize to arthropod pest infestations (Figure 2).

There is still a lack of knowledge about the combination of environmental factors such as drought and high temperatures on arthropod pest behavior and its effect on the physiology of the maize crop. Therefore, it is necessary to design and carry out experiments that can reveal different aspects of the combinations between stresses. To do this, it is required to adjust protocols for the exposure of plants to each type of stress so that they consider the same combination of factors that occur under field conditions. It is also recommended to evaluate agronomic strategies to improve tolerance to the combination of abiotic and biotic stresses. Some of these strategies may include soil management, irrigation practices, selection of the most appropriate crop varieties, and the application of genome and transgenic editing tools and technologies.

\section{AUTHOR CONTRIBUTIONS}

CC-A and HR-D wrote the manuscript. GL-M and AR-G revised and critically evaluated the manuscript. All authors contributed to the article and approved the submitted version.

\section{FUNDING}

The authors acknowledge funding from the Facultad de Ciencias Agrarias, Universidad Nacional de Colombia, campus Bogotá.

Andama, J. B., Mujiono, K., Hojo, Y., Shinya, T., and Galis, I. (2020). Nonglandular silicified trichomes are essential for rice defense against chewing herbivores. Plant Cell Environ. 43, 2019-2032. doi: 10.1111/pce.13775

Aslam, M., Maqbool, M. A., and Cengiz, R. (2015). Drought Stress in Maize Zea Mays L.). Cham: Springer International Publishing AG.

Atkinson, N. J., and Urwin, P. E. (2012). The interaction of plant biotic and abiotic stresses: from genes to the field. J. Exp. Bot. 63, 3523-3543. doi: 10.1093/jxb/ ers 100

Awasthi, R., Kaushal, N., Vadez, V., Turner, N. C., Berger, J., Siddique, K. H., et al. (2014). Individual and combined effects of transient drought and heat stress on carbon assimilation and seed filling in chickpea. Funct. Plant Biol. 41, 1148-1167. doi: 10.1071/FP13340

Ayub, M., Ashraf, M. Y., Kausar, A., Saleem, S., Anwar, S., Altay, V., et al. (2020). Growth and physio-biochemical responses of maize (Zea mays L.) to drought and heat stresses. Pl. Biosystems 155, 535-542. doi: 10.1080/11263504.2020. 1762785 
Bai, Y., Kissoudis, C., Yan, Z., Visser, R. G. F., and van der Linden, G. (2018). Plant behaviour under combined stress: tomato responses to combined salinity and pathogen stress. Plant J. 93, 781-793. doi: 10.1111/tpj.13800

Bajji, M., Kinet, J. M., and Lutts, S. (2002). The use of the electrolyte leakage method for assessing cell membrane stability as a water stress tolerance test in durum wheat. Plant Growth Regul. 36, 61-70. doi: 10.1023/A:1014732714549

Bandyopadhyay, A., Bose, I., and Chattopadhyay, K. (2019). Osmolytes ameliorate the effects of stress in the absence of the heat shock protein Hsp104 in Saccharomyces cerevisiae. PLoS One 14:e0222723. doi: 10.1371/journal.pone. 0222723

Bansal, S. (2015). "The interactive effects of drought and herbivory on ecophysiology of trees," in Combined Stresses in Plants, ed. R. Mahalingam (Cham: Springer), 245-259. doi: 10.1007/978-3-319-07899-1_12

Bedada, L. T., Seth, M. S., Runo, S. M., Teffera, W., Mugoya, C., Masiga, C. W., et al. (2016). Drought tolerant tropical maize (Zea mays L.) developed through genetic transformation with isopentenyltransferase gene. Afr. J. Biotechnol. 15, 2447-2464. doi: 10.5897/AJB2016.15228

Bielach, A., Hrtyan, M., and Tognetti, V. B. (2017). Plants under stress: involvement of auxin and cytokinin. Int. J. Mol. Sci. 18:E1427. doi: 10.3390/ijms18071427

Birkemoe, T., Bergmann, S., Hasle, T. E., and Klanderud, K. (2016). Experimental warming increases herbivory by leaf-chewing insects in an alpine plant community. Ecol. Evol. 6, 6955-6962. doi: 10.1002/ece3.2398

Block, A. K., Vaughan, M. M., Schmelz, E. A., and Christensen, S. A. (2019). Biosynthesis and function of terpenoid defense compounds in maize (Zea mays). Planta 249, 21-30. doi: 10.1007/s00425-018-2999-2

Blum, A. (2017). Osmotic adjustment is a prime drought stress adaptive engine in support of plant production. Plant Cell Environ. 40, 4-10. doi: 10.1111/pce. 12800

Bonnet, C., Lassueur, S., Ponzio, C., Gols, R., Dicke, M., and Reymond, P. (2017). Combined biotic stresses trigger similar transcriptomic responses but contrasting resistance against a chewing herbivore in Brassica nigra. BMC Plant Biol 17:127.

Burgess, P., and Huang, B. (2016). Leaf protein abundance associated with improved drought tolerance by elevated carbon dioxide in creeping bentgrass. J. Am. Soc. Hortic. Sci. 141, 85-96. doi: 10.21273/jashs.141.1.85

Cairns, J. E., Crossa, J., Zaidi, P. H., Grudloyma, P., Sanchez, C., Araus, J. L., et al. (2013). Identification of drought, heat, and combined drought and heat tolerant donors in maize. Crop Sci. 53, 1335-1346. doi: 10.2135/cropsci2012.09.0545

Carvalho, L. C., Coito, J. L., Gonçalves, E. F., Chaves, M. M., and Amâncio, S. (2016). Differential physiological response of the grapevine varieties Touriga Nacional and Trincadeira to combined heat, drought and light stresses. Plant Biol. 18, 101-111. doi: 10.1111/plb.12410

Casaretto, J. A., El-kereamy, A., Zeng, B., Stiegelmeyer, S. M., Chen, X., Bi, Y. M., et al. (2016). Expression of OsMYB55 in maize activates stress-responsive genes and enhances heat and drought tolerance. BMC Genomics 17:312.

Cheikh, N., and Jones, R. N. (1994). Disruption of maize kernel growth and development by heat stress. Plant Physiol. 106, 45-51. doi: 10.1104/pp.106.1.45

Chen, J. P., Xu, W. W., Burke, J., and Xin, Z. G. (2010). Role of phosphatidic acid in high temperature tolerance in maize. Crop Sci. 50, 2506-2515. doi: 10.2135/cropsci2009.12.0716

Chojak-Koźniewska, J., Kuźniak, E., and Zimny, J. (2018). The effects of combined abiotic and pathogen stress in plants: insights from salinity and Pseudomonas syringae pv lachrymans interaction in cucumber. Front. Plant Sci 9:1691. doi: 10.3389/fpls.2018.01691

Cohen, I., Zandalinas, S. I., Huck, C., Fritschi, F. B., and Mittler, R. (2021). Metaanalysis of drought and heat stress combination impact on crop yield and yield components. Physiol. Plant 171, 66-76. doi: 10.1111/ppl.13203

Copolovici, L., Kännaste, A., Remmel, T., and Niinemets, Ü (2014). Volatile organic compound emissions from Alnus glutinosa under interacting drought and herbivory stresses. Environ. Exp. Bot 100, 55-63. doi: 10.1016/j.envexpbot.2013. 12.011

Cornelissen, T. (2011). Climate change and its effects on terrestrial insects and herbivory patterns. Neotrop. Entomol 40, 155-163. doi: 10.1590/s1519$566 \times 2011000200001$

Dalal, V. K., and Tripathy, B. C. (2018). Water-stress induced downsizing of light-harvesting antenna complex protects developing rice seedlings from photo-oxidative damage. Sci. Rep. 8:5955. doi: 10.1038/s41598-017-14419-4
Davila Olivas, N. H., Coolen, S., Huang, P., Severing, E., van Verk, M. C., Hickman, R., et al. (2016). Effect of prior drought and pathogen stress on Arabidopsis transcriptome changes to caterpillar herbivory. New Phytol. 210, 1344-1356. doi: 10.1111/nph.13847

DeLucia, E. H., Nabity, P. D., Zavala, J. A., and Berenbaum, M. R. (2012). Climate change: resetting plant-insect interactions. Plant Physiol. 160, 1677-1685. doi: 10.1104/pp.112.20475

Dhanyalakshmi, K. H., Soolanayakanahally, R. Y., Rahman, T., Tanino, K. T., and Nataraja, K. N. (2019). "Leaf cuticular wax, a trait for multiple stress resistance in crop plants," in Abiotic and Biotic Stress in Plants, ed. B. A. De Oliveira (London: IntechOpen).

Dobra, J., Motyka, V., Dobrev, P., Malbeck, J., Prasil, I. T., Haisel, D., et al. (2010). Comparison of hormonal responses to heat, drought and combined stress in tobacco plants with elevated proline content. J. Plant Physiol. 167, 1360-1370. doi: 10.1016/j.jplph.2010.05.013

Dong, Q., Wang, W., Kunkel, K. E., Shao, Q., Xing, W., and Wei, J. (2020). Heterogeneous response of global precipitation concentration to global warming. Int. J. Climatol. 40, 1-13. doi: 10.1002/joc.6851

ElBasyoni, I., Saadalla, M., Baenziger, S., Bockelman, H., and Morsy, S. (2017). Cell membrane stability and association mapping for drought and heat tolerance in a worldwide wheat collection. Sustain 9:1606. doi: 10.3390/su9091606

Fahad, S., Bajwa, A. A., Nazir, U., Anjum, S. A., Farooq, A., Zohaib, A., et al. (2017). Crop production under drought and heat stress: plant responses and management options. Front. Plant Sci. 8:1147. doi: 10.3389/fpls.2017.01147

Gatehouse, J. A. (2002). Plant resistance towards insect herbivores: a dynamic interaction. New phytol 156, 145-169. doi: 10.1046/j.1469-8137.2002.00519.x

Gely, C., Laurance, S. G., and Stork, N. E. (2020). How do herbivorous insects respond to drought stress in trees? Biol. Rev. 95, 434-448. doi: 10.1111/brv. 12571

Ghannoum, O. (2009). C4 photosynthesis and water stress. Ann. Bot. 103, 635-644. doi: $10.1093 / \mathrm{aob} / \mathrm{mcn} 093$

Glauser, G., Marti, G., Villard, N., Doyen, G. A., Wolfender, J. L., Turlings, T. C., et al. (2011). Induction and detoxification of maize 1, 4-benzoxazin-3-ones by insect herbivores. Plant J. 68, 901-911. doi: 10.1111/j.1365-313x.2011.04740.x

Gomes, E. S., Santos, V., and Ávila, C. J. (2017). Biology and fertility life table of Helicoverpa armigera (Lepidoptera: Noctuidae) in different hosts. Entomol. Sci. 20, 419-426. doi: 10.1111/ens.12267

Grigorova, B., Vaseva, I. I., Demirevska, K., and Feller, U. (2011). Expression of selected heat shock proteins after individually applied and combined drought and heat stress. Acta Physiol. Plant 33, 2041-2049. doi: 10.1007/s11738-0110733-9

Grinnan, R., Carter, T. E., and Johnson, M. T. (2013). Effects of drought, temperature, herbivory, and genotype on plant-insect interactions in soybean (Glycine max). Arthropod-Plant Interact 7, 201-215. doi: 10.1007/s11829-0129234-z

Guo, M., Liu, J. H., Ma, X., Luo, D. X., Gong, Z. H., and Lu, M. H. (2016). The plant heat stress transcription factors (HSFs): structure, regulation, and function in response to abiotic stresses. Front. Plant Sci. 7:114. doi: 10.3389/fpls.2016. 00114

Guo, R., Shi, L., Jiao, Y., Li, M., Zhong, X., Gu, F., et al. (2018). Metabolic responses to drought stress in the tissues of drought-tolerant and drought-sensitive wheat genotype seedlings. Aob Plants 10:ly016. doi: 10.1093/aobpla/ply016

Gutbrodt, B., Dorn, S., and Mody, K. (2012). Drought stress affects constitutive but not induced herbivore resistance in apple plants. Arthropod Plant Inte. 6, 171-179. doi: 10.1007/s11829-011-9173-0

Gutbrodt, B., Mody, K., and Dorn, S. (2011). Drought changes plant chemistry and causes contrasting responses in lepidopteran herbivores. Oikos 120, 1732-1740. doi: 10.1111/j.1600-0706.2011.19558.x

Haider, I., Andreo-Jimenez, B., Bruno, M., Bimbo, A., Floková, K., Abuauf, H., et al. (2018). The interaction of strigolactones with abscisic acid during the drought response in rice. J. Exp. Bot. 69, 2403-2414. doi: 10.1093/jxb/ery089

Havko, N. E., Das, M. R., McClain, A. M., Kapali, G., Sharkey, T. D., and Howe, G. A. (2020). Insect herbivory antagonizes leaf cooling responses to elevated temperature in tomato. Proc. Natl. Acad. Sci. U.S.A. 117, 2211-2217. doi: 10. 1073/pnas.1913885117

Haworth, M., Marino, G., Brunetti, C., Killi, D., De Carlo, A., and Centritto, M. (2018). The impact of heat stress and water deficit on the photosynthetic and 
stomatal physiology of olive (Olea europaea L.) - A case study of the 2017 heat wave. Plants 7:76. doi: 10.3390/plants7040076

Hu, S., Ding, Y., and Zhu, C. (2020). Sensitivity and responses of chloroplasts to heat stress in plants. Front. Plant Sci. 11:375. doi: 10.3389/fpls.2020.00375

Hu, X., Li, Y., Li, C., Yang, H., Wang, W., and Lu, M. (2010). Characterization of small heat shock proteins associated with maize tolerance to combined drought and heat stress. J. Plant Growth Regul. 29, 455-464. doi: 10.1007/s00344-0109157-9

Hu, X., Wu, L., Zhao, F., Zhang, D., Li, N., Zhu, G., et al. (2015). Phosphoproteomic analysis of the response of maize leaves to drought, heat and their combination stress. Front. Plant Sci. 6:298. doi: 10.3389/fpls.2015.00298

Huang, T., Jander, G., and de Vos, M. (2011). Non-protein amino acids in plant defense against insect herbivores: representative cases and opportunities for further functional analysis. Phytochemistry 72, 1531-1537. doi: 10.1016/j. phytochem.2011.03.019

Hussain, H. A., Hussain, S., Khaliq, A., Ashraf, U., Anjum, S. A., Men, S., et al. (2018). Chilling and drought stresses in crop plants: implications, cross talk, and potential management opportunities. Front. Plant Sci. 9:393. doi: 10.3389/ fpls.2018.00393

Hussain, H. A., Men, S., Hussain, S., Chen, Y., Ali, S., Zhang, S., et al. (2019). Interactive effects of drought and heat stresses on morpho-physiological attributes, yield, nutrient uptake and oxidative status in maize hybrids. Sci. Rep. 9, 1-12.

Ilík, P., Spundova, M., Sicner, M., Melkovicova, H., Kucerova, Z., Krchnak, P., et al. (2018). Methods Estimating heat tolerance of plants by ion leakage: a new method based on gradual heating. New Phytol. 218, 1278-1287. doi: 10.1111/ nph.15097

Ivanov, A. G., Velitchkova, M. Y., Allakhverdiev, S. I., and Huner, N. P. A. (2017). Heat stress-induced effects of photosystem I: an overview of structural and functional responses. Photosynth. Res. 133, 17-30. doi: 10.1007/s11120-017$0383-\mathrm{x}$

Kaur, G., and Asthir, B. (2017). Molecular responses to drought stress in plants. Biol. Plant 61, 201-209.

Khan, S., Anwar, S., Ashraf, M. Y., Khaliq, B., Sun, M., Hussain, S., et al. (2019). Mechanisms and Adaptation Strategies to Improve Heat Tolerance in Rice. A Rev.. Plants 8:508. doi: 10.3390/plants8110508

Khan, Z., and Shahwar, D. (2020). "Role of heat shock proteins (HSPs) and heat stress tolerance in crop plants," in Sustainable Agriculture in the Era of Climate Change, eds R. Roychowdhury, S. Choudhury, M. Hasanuzzaman, and S. Srivastava (Cham: Springer), 211-234. doi: 10.1007/978-3-030-45669-6_9

Kido, ÉA., Ferreira-Neto, J. R. C., da Silva, M. D., Santos, V. E. P., da Silva Filho, J. L. B., and Benko-Iseppon, A. M. (2019). "Osmoprotectant-related genes in plants under abiotic stress: expression dynamics," in Silico Genome Mapping, and Biotechnology,". in Osmoprotectant-Mediated Abiotic Stress Tolerance in Plants, eds M. Hossain, V. Kumar, D. Burritt, M. Fujita, and P. Mäkelä (Cham: Springer), 1-40. doi: 10.1007/978-3-030-27423-8_1

Killi, D., Bussotti, F., Raschi, A., and Haworth, M. (2017). Adaptation to high temperature mitigates the impact of water deficit during combined heat and drought stress in C3 sunflower and C4 maize varieties with contrasting drought tolerance. Physiol. Plant. 159, 130-147. doi: 10.1111/ppl.12490

Killi, D., Raschi, A., and Bussotti, F. (2020). Lipid Peroxidation and Chlorophyll Fluorescence of Photosystem II Performance during Drought and Heat Stress is Associated with the Antioxidant Capacities of C3 Sunflower and C4 Maize Varieties. Int. J. Mol. Sci. 21:4846. doi: 10.3390/ijms21144846

Lamaoui, M., Jemo, M., Datla, R., and Bekkaoui, F. (2018). Heat and drought stresses in crops and approaches for their mitigation. Front. Chem. 6:26. doi: 10.3389/fchem.2018.00026

Li, L., Gu, W., Li, J., Li, C., Xie, T., Qu, D., et al. (2018). Exogenously applied spermidine alleviates photosynthetic inhibition under drought stress in maize (Zea mays L.) seedlings associated with changes in endogenous polyamines and phytohormones. Plant Physiol. Biochem. 129, 35-55. doi: 10.1016/j.plaphy.2018. 05.017

Li, X., and Cao, J. (2016). Late Embryogenesis Abundant (LEA) gene family in maize: identification, evolution, and expression profiles. Plant Mol. Biol. Rep 34, 15-28. doi: 10.1007/s11105-015-0901-y

Lipiec, J., Doussan, C., Nosalewicz, A., and Kondracka, K. (2013). Effect of drought and heat stresses on plant growth and yield: a review. Int. Agrophys 27, 463-477. doi: 10.2478/intag-2013-0017
Liu, Z., Qin, J., Tian, X., Xu, S., Wang, Y., Li, H., et al. (2018). Global profiling of alternative splicing landscape responsive to drought, heat and their combination in wheat (Triticum aestivum L.). Plant Biotechnol. J. 16, 714-726. doi: 10.1111/pbi.12822

Magwanga, R. O., Lu, P., Kirungu, J. N., Lu, H., Wang, X., Cai, X., et al. (2018). Characterization of the late embryogenesis abundant (LEA) proteins family and their role in drought stress tolerance in upland cotton. BMC Genet. 19:6.

Manandhar, R., and Wright, M. G. (2016). Effects of interplanting flowering plants on the biological control of corn earworm (Lepidoptera: Noctuidae) and thrips (Thysanoptera: Thripidae) in sweet corn. J. Econ. Entomol. 109, 113-119. doi: 10.1093/jee/tov306

Mathur, S., Agrawal, D., and Jajoo, A. (2014). Photosynthesis: response to high temperature stress. J. Photochem. Photobiol. B 137, 116-126. doi: 10.1016/j. jphotobiol.2014.01.010

Mathur, S., Sharma, M. P., and Jajoo, A. (2018). Improved photosynthetic efficacy of maize (Zea mays) plants with arbuscular mycorrhizal fungi (AMF) under high temperature stress. J. Photochem. Photobiol. B, Biol. 180, 149-154. doi: 10.1016/j.jphotobiol.2018.02.002

Mitchell, C., Brennan, R. M., Graham, J., and Karley, A. J. (2016). Plant defense against herbivorous pests: exploiting resistance and tolerance traits for sustainable crop protection. Front. Plant Sci. 7:1132. doi: 10.3389/fpls.2016. 01132

Mithöfer, A., and Boland, W. (2012). Plant defense against herbivores: chemical aspects. Ann. Rev. Plant Biol 63, 431-450. doi: 10.1146/annurev-arplant042110-103854

Mittler, R. (2006). Abiotic stress, the field environment and stress combination. Trends Plant Sci. 11, 15-19. doi: 10.1016/j.tplants.2005.11.002

Mittler, R., and Blumwald, E. (2010). Genetic engineering for modern agriculture: challenges and perspectives. Annu. Rev. Plant Biol. 61, 443-462. doi: 10.1146/ annurev-arplant-042809-112116

Moya-Raygoza, G. (2016). Early development of leaf trichomes is associated with decreased damage in teosinte, compared with maize, by Spodoptera frugiperda (Lepidoptera: Noctuidae). Ann. Entomol. Soc. Am. 109, 737-743. doi: 10.1093/ aesa/saw049

Nagaraju, M., Kumar, S. A., Reddy, P. S., Kumar, A., Rao, D. M., and Kavi Kishor, P. B. (2019). Genome-scale identification, classification, and tissue specific expression analysis of late embryogenesis abundant (LEA) genes under abiotic stress conditions in Sorghum bicolor L. PLoS One 14:e0209980. doi: 10.1371/ journal.pone.0209980

Nawaz, F., Naeem, M., Ashraf, M. Y., Tahir, M. N., Zulfiqar, B., Salahuddin, M., et al. (2016). Selenium supplementation affects physiological and biochemical processes to improve fodder yield and quality of maize (Zea mays L.) under water deficit conditions. Front. Plant Sci. 7:1438. doi: 10.3389/fpls.2016.01438

Neven, L. G. (2000). Physiological responses of insects to heat. Postharvest Biol. Tec. 21, 103-111. doi: 10.1016/s0925-5214(00)00169-1

Nguyen, D., D’agostino, N., Tytgat, T. O., Sun, P., Lortzing, T., Visser, E. J., et al. (2016). Drought and flooding have distinct effects on herbivore-induced responses and resistance in Solanum dulcamara. Plant Cell Environ. 39, 14851499. doi: 10.1111 pce. 12708

Nguyen, D., Poeschl, Y., Lortzing, T., Hoogveld, R., Gogol-Döring, A., Cristescu, S. M., et al. (2018). Interactive responses of Solanum dulcamara to drought and insect feeding are herbivore species-specific. Int. J. M. Sci. 19:3845. doi: 10.3390/ijms19123845

Nijabat, A., Bolton, A., Mahmood-ur-Rehman, M., Ijaz Shah, A., Hussain, R., Naveed, N. H., et al. (2020). Cell membrane stability and relative cell injury in response to heat stress during early and late seedling stages of diverse carrot (Daucus carota L.) germplasm. Hortscience 55, 1446-1452. doi: 10.21273/ HORTSCI15058-20

Noman, A., Ali, S., Naheed, F., Ali, Q., Farid, M., Rizwan, M., et al. (2015). Foliar application of ascorbate enhances the physiological and biochemical attributes of maize (Zea mays L.) cultivars under drought stress. Arch. Agron. Soil Sci. 61, 1659-1672. doi: 10.1080/03650340.2015.1028379

Obata, T., Witt, S., Lisec, J., Palacios-Rojas, N., Florez-Sarasa, I., Yousfi, S., et al. (2015). Metabolite profiles of maize leaves in drought, heat, and combined stress field trials reveal the relationship between metabolism and grain yield. Plant Physiol. 169, 2665-2683. doi: 10.1104/pp.15.01164

Ortiz-Carreon, F. R., Rojas, J. C., Cisneros, J., and Malo, E. A. (2019). Herbivoreinduced volatiles from maize plants attract Chelonus insularis, an egg-larval 
parasitoid of the fall armyworm. J. Chem. Ecol. 45, 326-337. doi: 10.1007/ s10886-019-01051-x

Osmolovskaya, N., Shumilina, J., Kim, A., Didio, A., Grishina, T., Bilova, T., et al. (2018). Methodology of drought stress research: Experimental setup and physiological characterization. Int. J. Mol. Sci. 19:4089. doi: 10.3390/ ijms19124089

Pandey, P., Irulappan, V., Bagavathiannan, M. V., and Senthil-Kumar, M. (2017). Impact of combined abiotic and biotic stresses on plant growth and avenues for crop improvement by exploiting physio-morphological traits. Front. Plant Sci. 8:537. doi: 10.3389/fpls.2017.00537

Pannuti, L. E. R., Paula-Moraes, S. V., Hunt, T. E., Baldin, E. L. L., Dana, L., and Malaquias, J. V. (2016). Plant-to-plant movement of Striacosta albicosta (Lepidoptera: Noctuidae) and Spodoptera frugiperda (Lepidoptera: Noctuidae) in maize (Zea mays). J. Econ. Entomol. 109, 1125-1131. doi: 10.1093/jee/tow042

Pedrosa, A. M., Martins, C. D. P. S., Goncalves, L. P., and Costa, M. G. C. (2015). Late embryogenesis abundant (LEA) constitutes a large and diverse family of proteins involved in development and abiotic stress responses in sweet orange (Citrus sinensis L. Osb.). PLoS One 10:e0145785. doi: 10.1371/journal.pone. 0145785

Perdomo, J. A., Capó-Bauçà, S., Carmo-Silva, E., and Galmés, J. (2017). Rubisco and rubisco activase play an important role in the biochemical limitations of photosynthesis in rice, wheat, and maize under high temperature and water deficit. Front. Plant Sci. 8:490. doi: 10.3389/fpls.2017.00490

Perdomo, J. A., Conesa, M. À, Medrano, H., Ribas-Carbó, M., and Galmés, J. (2015). Effects of long-term individual and combined water and temperature stress on the growth of rice, wheat and maize: relationship with morphological and physiological acclimation. Physiol. Plant 155, 149-165. doi: 10.1111/ppl. 12303

Peykanpour, E., Ghehsareh, A. M., Fallahzade, J., and Najarian, M. (2016). Interactive effects of salinity and ozonated water on yield components of cucumber. Plant Soil Environ. 62, 361-366. doi: 10.17221/170/2016-pse

Pliūra, A., Jankauskienė, J., Bajerkevičienè, G., Lygis, V., Suchockas, V., Labokas, J., et al. (2019). Response of juveniles of seven forest tree species and their populations to different combinations of simulated climate change-related stressors: spring-frost, heat, drought, increased UV radiation and ozone concentration under elevated CO 2 level. J. Plant Res. 132, 789-811. doi: 10.1007/s10265-019-01146-2

Prasad, P. V. V., Staggenborg, S., and Ristic, Z. (2008). "Impacts of drought and/or heat stress on physiological, developmental, growth, and yield processes of crop plants," in Response of Crops to Limited Water: Understanding and Modeling Water Stress Effects on Plant Growth Processes: Advances in Agricultural Systems Modeling Series 1, eds L. R. Ahuja, V. R. Reddy, S. A. Saseendran, and Q. Yu (Madison, WI: ASA-CSSA-SSSA), 301-356. doi: 10.2134/advagricsystmodel1. c11

Priya, M., Dhanker, O. P., Siddique, K. H., HanumanthaRao, B., Nair, R. M., Pandey, S., et al. (2019). Drought and heat stress-related proteins: an update about their functional relevance in imparting stress tolerance in agricultural crops. Theor. Appl. Genet. 132, 1607-1638. doi: 10.1007/s00122-019-03331-2

Qi, J., ul Malook, S., Shen, G., Gao, L., Zhang, C., Li, J., et al. (2018). Current understanding of maize and rice defense against insect herbivores. Plant Divers 40, 189-195. doi: 10.1016/j.pld.2018.06.006

Raja, V., Qadir, S. U., Alyemeni, M. N., and Ahmad, P. (2020). Impact of drought and heat stress individually and in combination on physiobiochemical parameters, antioxidant responses, and gene expression in Solanum lycopersicum. 3 Biotech 10:208.

Redondo-Gómez, S. (2013). "Abiotic and biotic stress tolerance in plants," in Molecular Stress Physiology of Plants, eds G. Rout and A. Das (India: Springer), 1-20. doi: 10.1007/978-81-322-0807-5_1

Rejeb, I. B., Pastor, V., and Mauch-Mani, B. (2014). Plant responses to simultaneous biotic and abiotic stress: molecular mechanisms. Plants 3, 458475. doi: 10.3390/plants3040458

Robert, C. A., Schirmer, S., Barry, J., Wade French, B., Hibbard, B. E., and Gershenzon, J. (2015). Belowground herbivore tolerance involves delayed overcompensatory root regrowth in maize. Entomol. Exp. Appl. 157, 113-120. doi: $10.1111 /$ eea. 12346

Rodríguez-Calzada, T., Qian, M., Strid, Å, Neugart, S., Schreiner, M., TorresPacheco, I., et al. (2019). Effect of UV-B radiation on morphology, phenolic compound production, gene expression, and subsequent drought stress responses in chili pepper (Capsicum annuum L.). Plant Physiol. Biochem. 134, 94-102. doi: 10.1016/j.plaphy.2018.06.025

Russo, M. L., Scorsetti, A. C., Vianna, M. F., Cabello, M., Ferreri, N., and Pelizza, S. (2019). Endophytic effects of Beauveria bassiana on corn (Zea mays) and its herbivore, Rachiplusia nu (lepidoptera: Noctuidae). Insects 10:110. doi: 10.3390/ insects 10040110

Sabagh, A. E., Hossain, A., Iqbal, M. A., Barutçular, C., Islam, M. S., Çiğ, F., et al. (2020). "Maize adaptability to heat stress under changing climate," in Plant Stress Physiology, ed. A. Hossain (London: IntechOpen).

Sah, R. P., Chakraborty, M., Prasad, K., Pandit, M., Tudu, V. K., Chakravarty, M. K., et al. (2020). Impact of water deficit stress in maize: Phenology and yield components. Sci. Rep. 10, 1-15.

Sahin, U., Ekinci, M., Ors, S., Turan, M., Yildiz, S., and Yildirim, E. (2018). Effects of individual and combined effects of salinity and drought on physiological, nutritional and biochemical properties of cabbage (Brassica oleracea var. capitata). Sci. Hortic. 240, 196-204. doi: 10.1016/j.scienta.2018.06.016

Santamaria, M. E., Martínez, M., Cambra, I., Grbic, V., and Diaz, I. (2013). Understanding plant defence responses against herbivore attacks: an essential first step towards the development of sustainable resistance against pests. Transgenic Res. 22, 697-708. doi: 10.1007/s11248-013-9725-4

Sattar, A., Sher, A., Ijaz, M., Ul-Allah, S., Rizwan, M. S., Hussain, M., et al. (2020). Terminal drought and heat stress alter physiological and biochemical attributes in flag leaf of bread wheat. PLoS One 15:e0232974. doi: 10.1371/journal.pone. 0232974

Schmelz, E. A., Huffaker, A., Sims, J. W., Christensen, S. A., Lu, X., Okada, K., et al. (2014). Biosynthesis, elicitation and roles of monocot terpenoid phytoalexins. Plant J. 79, 659-678. doi: 10.1111/tpj.12436

Scott, E. R., Li, X., Kfoury, N., Morimoto, J., Han, W. Y., Ahmed, S., et al. (2019). Interactive effects of drought severity and simulated herbivory on tea (Camellia sinensis) volatile and non-volatile metabolites. Environ. Exp. Bot. 157, 283-292. doi: 10.1016/j.envexpbot.2018.10.025

Sehgal, A., Sita, K., Bhandari, K., Kumar, S., Kumar, J., Vara Prasad, P. V., et al. (2019). Influence of drought and heat stress, applied independently or in combination during seed development, on qualitative and quantitative aspects of seeds of lentil (Lens culinaris Medikus) genotypes, differing in drought sensitivity. Plant Cell Environ. 42, 198-211. doi: 10.1111/pce.13328

Sehgal, A., Sita, K., Kumar, J., Kumar, S., Singh, S., Siddique, K. H., et al. (2017). Effects of drought, heat and their interaction on the growth, yield and photosynthetic function of lentil (Lens culinaris Medikus) genotypes varying in heat and drought sensitivity. Front. Plant Sci. 8:1776. doi: 10.3389/fpls.2017. 01776

Sewelam, N., Oshima, Y., Mitsuda, N., and Ohme-Takagi, M. (2014). A step towards understanding plant responses to multiple environmental stresses: a genome-wide study. Plant Cell Environ. 37, 2024-2035. doi: 10.1111/pce. 12274

Sgherri, C., Pérez-López, U., Micaelli, F., Miranda-Apodaca, J., Mena-Petite, A., Muñoz-Rueda, A., et al. (2017). Elevated CO2 and salinity are responsible for phenolics-enrichment in two differently pigmented lettuces. Plant Physiol. Biochem. 115, 269-278. doi: 10.1016/j.plaphy.2017.04.006

Shafqat, W., Jaskani, M. J., Maqbool, R., Chattha, W. S., Ali, Z., Naqvi, S. A., et al. (2021). Heat shock protein and aquaporin expression enhance water conserving behavior of citrus under water deficits and high temperature conditions. Environ. Exp. Bot. 181:104270. doi: 10.1016/j.envexpbot.2020.104270

Shah, N. H., and Paulsen, G. M. (2003). Interaction of drought and high temperature on photosynthesis and grain-filling of wheat. Plant Soil 257, 219-226. doi: 10.1023/A:1026237816578

Shehzad, M., Gulzar, A., Staley, J. T., and Tariq, M. (2021). The effects of drought stress and type of fertiliser on generalist and specialist herbivores and their natural enemies. Ann. Appl. Biol. 178, 377-386. doi: 10.1111/aab.12654

Shi, J., Gao, H., Wang, H., Lafitte, H. R., Archibald, R. L., Yang, M., et al. (2017). ARGOS8 variants generated by CRISPR-Cas9 improve maize grain yield under field drought stress conditions. Plant Biotechnol. J. 15, 207-216. doi: 10.1111/ pbi. 12603

Silva, E. N., Ferreira-Silva, S. L., de Vasconcelos Fontenele, A., Ribeiro, R. V., Viégas, R. A., and Silveira, J. A. G. (2010). Photosynthetic changes and protective mechanisms against oxidative damage subjected to isolated and combined drought and heat stresses in Jatropha curcas plants. J. Plant Physiol. 167, 1157-1164. doi: 10.1016/j.jplph.2010.03.005 
Sunoj, V. J., Shroyer, K. J., Jagadish, S. K., and Prasad, P. V. (2016). Diurnal temperature amplitude alters physiological and growth response of maize (Zea mays L.) during the vegetative stage. Environ. Exp. Bot. 130, 113-121. doi: 10.1016/j.envexpbot.2016.04.007

Suzuki, N. (2016a). Hormone signaling pathways under stress combinations. Plant Signal. Behav. 11:e1247139. doi: 10.1080/15592324.2016.1247139

Suzuki, N., Basil, E., Hamilton, J. S., Inupakutika, M. A., Madhuri, A., Zandalinas, S. I., et al. (2016b). ABA is required for plant acclimation to a combination of salt and heat stress. PLoS One 11:e0147625. doi: 10.1371/journal.pone.014 7625

Suzuki, N., Rivero, R. M., Shulaev, V., Blumwald, E., and Mittler, R. (2014). Abiotic and biotic stress combinations. New Phytol. 203, 32-43. doi: 10.1111/nph. 12797

Takele, A. (2010). Differential responses of electrolyte leakage and pigment compositions in maize and sorghum after exposure to and recovery from pre- and post-flowering dehydration. Agr. Sci. China 9, 813-824. doi: 10.1016/ S1671-2927(09)60159-0

Talaat, N. B. (2020). 24-Epibrassinolide and Spermine combined treatment sustains maize (Zea mays L.) drought tolerance by improving photosynthetic efficiency and altering phytohormones profile. J. Soil Sci. Plant Nut. 20, 516529. doi: 10.1007/s42729-019-00138-4

Tani, E., Kizis, D., Markellou, E., Papadakis, I., Tsamadia, D., Leventis, G., et al. (2018). Cultivar-dependent responses of eggplant (Solanum melongena L.) to simultaneous Verticillium dahliae infection and drought. Front. Plant Sci. 9:1181. doi: $10.3389 /$ fpls.2018.01181

Terada, R., Matsumoto, K., Borlongan, I. A., Watanabe, Y., Nishihara, G. N., Endo, H., et al. (2018). The combined effects of PAR and temperature including the chilling-light stress on the photosynthesis of a temperate brown alga, Sargassum patens (Fucales), based on field and laboratory measurements. J. Appl. Phycol. 30, 1893-1904. doi: 10.1007/s10811-017-1344-7

Tesfaye, K., Kruseman, G., Cairns, J. E., Zaman-Allah, M., Wegary, D., Zaidi, P. H., et al. (2018). Potential benefits of drought and heat tolerance for adapting maize to climate change in tropical environments. Clim. Risk Manag. 19, 106-119. doi: 10.1016/j.crm.2017.10.001

Tian, F. X., Gong, J. F., and Zhang, J. (2013). Enhanced stability of thylakoid membrane proteins and antioxidant competence contribute to drought stress resistance in the tasg1 wheat stay-green mutant. J. Exp. Bot. 64, 1509-1520. doi: $10.1093 /$ jxb/ert004

Tiwari, Y. K., and Yadav, S. K. (2019). High temperature stress tolerance in maize (Zea mays L.): physiological and molecular mechanisms. J. Plant Biol. 62, 93-102. doi: $10.1007 / \mathrm{s} 12374-018-0350-\mathrm{x}$

Turnbull, T. L., Adams, M. A., and Warren, C. R. (2007). Increased photosynthesis following partial defoliation of field-grown Eucalyptus globulus seedlings is not caused by increased leaf nitrogen. Tree Physiol. 27, 1481-1492. doi: 10.1093/ treephys/27.10.1481

Urban, O., Hlaváčová, M., Klem, K., Novotná, K., Rapantová, B., Smutná, P., et al. (2018). Combined effects of drought and high temperature on photosynthetic characteristics in four winter wheat genotypes. Field Crops Res. 223, 137-149. doi: 10.1016/j.fcr.2018.02.029

van der Kooi, C. J., Reich, M., Löw, M., De Kok, L. J., and Tausz, M. (2016). Growth and yield stimulation under elevated $\mathrm{CO} 2$ and drought: a meta-analysis on crops. Environ. Exp. Bot. 122, 150-157. doi: 10.1016/j.envexpbot.2015. 10.004

Vaughan, M. M., Christensen, S., Schmelz, E. A., Huffaker, A., Mcauslane, H. J., Alborn, H. T., et al. (2015). Accumulation of terpenoid phytoalexins in maize roots is associated with drought tolerance. Plant Cell Environ. 38, 2195-2207. doi: $10.1111 /$ pce. 12482

Vemanna, R. S., Bakade, R., Bharti, P., Kumar, M. K., Sreeman, S. M., SenthilKumar, M., et al. (2019). Cross-talk signaling in rice during combined drought and bacterial blight stress. Front. Plant Sci. 10:193. doi: 10.3389/fpls.2019. 00193

Wang, Z., Li, G., Sun, H., Ma, L., Guo, Y., Zhao, Z., et al. (2018). Effects of drought stress on photosynthesis and photosynthetic electron transport chain in young apple tree leaves. Biol. Open 7:bio035279. doi: 10.1242/bio.035279

War, A. R., Paulraj, M. G., Ahmad, T., Buhroo, A. A., Hussain, B., Ignacimuthu, S., et al. (2012). Mechanisms of plant defense against insect herbivores. Plant Signal. Behav. 7, 1306-1320. doi: 10.4161/psb.21663
Weldegergis, B. T., Zhu, F., Poelman, E. H., and Dicke, M. (2015). Drought stress affects plant metabolites and herbivore preference but not host location by its parasitoids. Oecologia 177, 701-713. doi: 10.1007/s00442-014-3129-x

Wijewardene, I., Mishra, N., Sun, L., Smith, J., Zhu, X., Payton, P., et al. (2020). Improving drought-, salinity-, and heat-tolerance in transgenic plants by cooverexpressing Arabidopsis vacuolar pyrophosphatase gene AVP1 and Larrea Rubisco activase gene RCA. Plant Sci. 296:110499. doi: 10.1016/j.plantsci.2020. 110499

$\mathrm{Wu}$, J., and Baldwin, I. T. (2010). New insights into plant responses to the attack from insect herbivores. Annu. Rev. Genet. 44, 1-24. doi: 10.1146/annurevgenet-102209-163500

Yan, F., Liang, X., and Zhu, X. (1999). The role of DIMBOA on the feeding of Asian corn borer, Ostrinia furnacalis (Guenee) (Lep., Pyralidae). J. Appl. Entomol. 123, 49-53. doi: 10.1046/j.1439-0418.1999.00304.x

Yan, J., Lipka, A. E., Schmelz, E. A., Buckler, E. S., and Jander, G. (2015). Accumulation of 5-hydroxynorvaline in maize (Zea mays) leaves is induced by insect feeding and abiotic stress. J. Exp. Bot. 66, 593-602. doi: 10.1093/jxb/ eru385

Yan, X., Lu, J., Ren, M., He, Y., Wang, Y., Wang, Z., et al. (2020). Insecticidal activity of $11 \mathrm{Bt}$ toxins and 3 transgenic maize events expressing Vip3Aa19 to Black Cutworm, Agrotis ipsilon (Hufnagel). Insects 11:208. doi: 10.3390/ insects11040208

Yang, D., Ma, P., Liang, X., Wei, Z., Liang, Z., Liu, Y., et al. (2012). PEG and ABA trigger methyl jasmonate accumulation to induce the MEP pathway and increase tanshinone production in Salvia miltiorrhiza hairy roots. Physiol. Plant 146, 173-183. doi: 10.1111/j.1399-3054.2012.01603.x

Ye, J., Wang, S., Deng, X., Yin, L., Xiong, B., and Wang, X. (2016). Melatonin increased maize (Zea mays L.) seedling drought tolerance by alleviating drought-induced photosynthetic inhibition and oxidative damage. Acta Physiol. Plant 38:48.

Zampieri, M., Ceglar, A., Dentener, F., Dosio, A., Naumann, G., Van Den Berg, M., et al. (2019). When will current climate extremes affecting maize production become the norm? Earths Future 7, 113-122. doi: 10.1029/2018EF000995

Zandalinas, S. I., Balfagón, D., Arbona, V., and Gómez-Cadenas, A. (2017). Modulation of antioxidant defense system is associated with combined drought and heat stress tolerance in citrus. Front. Plant Sci. 8:953. doi: 10.3389/fpls.2017. 00953

Zandalinas, S. I., Mittler, R., Balfagón, D., Arbona, V., and GómezCadenas, A. (2018). Plant adaptations to the combination of drought and high temperatures. Physiol. Plant 162, 2-12. doi: 10.1111/ppl. 12540

Zhang, H., and Sonnewald, U. (2017). Differences and commonalities of plant responses to single and combined stresses. Plant J. 90, 839-855. doi: 10.1111/ tpj. 13557

Zhang, L., Gao, M., Hu, J., Zhang, X., Wang, K., and Ashraf, M. (2012). Modulation role of abscisic acid $(\mathrm{ABA})$ on growth, water relations and glycinebetaine metabolism in two maize (Zea mays L.) cultivars under drought stress. Int. J. Mol. Sci. 13, 3189-3202. doi: 10.3390/ijms13033189

Zhang, N., Carlucci, P., Nguyen, J., Hayes-Jackson, J. W., and Tonsor, S. (2016). Contrasting avoidance-tolerance in heat stress response from thermally contrasting climates in Arabidopsis thaliana. bioRxiv [Preprint] doi: 10.1101/ 044461

Zhang, X., Wang, X., Zhuang, L., Gao, Y., and Huang, B. (2019). Abscisic acid mediation of drought priming-enhanced heat tolerance in tall fescue (Festuca arundinacea) and Arabidopsis. Physiol. Plant. 167, 488-501. doi: 10.1111/ppl. 12975

Zhang, Y., Haihui, S., Wang, X., Zhou, X., Zhang, K., Chen, X., et al. (2020). The roles of different types of trichomes in tomato resistance to cold, drought, whiteflies, and botrytis. Agronomy 10, 411-426. doi: 10.3390/ agronomy10030411

Zhao, F., Zhang, D., Zhao, Y., Wang, W., Yang, H., Tai, F., et al. (2016). The difference of physiological and proteomic changes in maize leaves adaptation to drought, heat, and combined both stresses. Front. Plant Sci. 7:1471. doi: 10.3389/fpls.2016.01471

Zhou, R., Yu, X., Ottosen, C. O., Rosenqvist, E., Zhao, L., Wang, Y., et al. (2017). Drought stress had a predominant effect over heat stress on three tomato cultivars subjected to combined stress. BMC Plant Biol. 17:24. 
Zhou, S., Lou, Y. R., Tzin, V., and Jander, G. (2015). Alteration of plant primary metabolism in response to insect herbivory. Plant Physiol. 169, 1488-1498. doi: 10.1104/pp.15.01405

Zhou, Z. H., Wang, Y., Ye, X. Y., and Li, Z. G. (2018). Signaling molecule hydrogen sulfide improves seed germination and seedling growth of maize (Zea mays L.) under high temperature by inducing antioxidant system and osmolyte biosynthesis. Front. Plant Sci. 9:1288. doi: 10.3389/fpls.2018.01288

Zhu, F., Poelman, E. H., and Dicke, M. (2014). Insect herbivore-associated organisms affect plant responses to herbivory. New Phytol. 204, 315-321. doi: 10.1111/nph.12886

Zouari, M., Hassena, A. B., Trabelsi, L., Rouina, B. B., Decou, R., and Labrousse, P. (2019). "Exogenous proline-mediated abiotic stress tolerance in plants: possible mechanisms," in Osmoprotectant-Mediated Abiotic Stress Tolerance in Plants, eds M. Hossain, V. Kumar, D. Burritt, M. Fujita, and P. Mäkelä (Cham: Springer), 99-122. doi: 10.1007/978-3-030-27423-8_4
Zulfiqar, F., Akram, N. A., and Ashraf, M. (2020). Osmoprotection in plants under abiotic stresses: new insights into a classical phenomenon. Planta 251:3.

Conflict of Interest: The authors declare that the research was conducted in the absence of any commercial or financial relationships that could be construed as a potential conflict of interest.

Copyright (c) 2021 Chávez-Arias, Ligarreto-Moreno, Ramírez-Godoy and RestrepoDíaz. This is an open-access article distributed under the terms of the Creative Commons Attribution License (CC BY). The use, distribution or reproduction in other forums is permitted, provided the original author(s) and the copyright owner(s) are credited and that the original publication in this journal is cited, in accordance with accepted academic practice. No use, distribution or reproduction is permitted which does not comply with these terms. 